\title{
Yoropyrazone, a new naphthopyridazone alkaloid isolated from Streptomyces sp. IFM 11307 and evaluation of its TRAIL resistance-overcoming activity
}

\author{
Mohamed S Abdelfattah ${ }^{1}$, Kazufumi Toume ${ }^{2}$ and Masami Ishibashi ${ }^{2}$ \\ A new naphthopyridazone derivative, yoropyrazone (1), has been isolated from Streptomyces sp. IFM 11307. The structure of \\ the new compound was established on the basis of spectroscopic analyses. Compound $1(10 \mu \mathrm{M})$ in combination with TRAIL \\ moderately showed cytotoxic activity in sensitizing TRAIL-resistant human gastric adenocarcinoma (AGS) cells. \\ The Journal of Antibiotics (2012) 65, 245-248; doi:10.1038/ja.2012.11; published online 22 February 2012
}

Keywords: naphthopyridazone; Streptomyces sp.; TRAIL

\begin{abstract}
INTRODUCTION
During our continuous screening program for bioactive natural products from actinomycetes, ${ }^{1-3}$ we recently isolated Streptomyces sp. IFM 11307 from the soil of Yoro-valley, Ichihara, Chiba prefecture, Japan, and have reported the isolation of four new pyranonaphthoquinones and one new phenazine alkaloid, yorophenazine, with TRAIL resistance-overcoming activity from this strain. ${ }^{4}$ Further investigation of the culture extract of Streptomyces sp. IFM 11307 resulted in the isolation of another metabolite, yoropyrazone (1), possessing a naphthoiminoquinone-pyridazone structure. We herein describe the isolation and structure elucidation of $\mathbf{1}$ as well as the evaluation of TRAIL resistance-overcoming activity of $\mathbf{1}$ in human gastric adenocarcinoma (AGS) cell lines as we are interested in screening studies targeting the TRAIL-related cancer selective apoptosis-inducing pathway. ${ }^{5,6}$
\end{abstract}

\section{RESULTS AND DISCUSSION}

Streptomyces sp. IFM 11307 was cultivated on Waksman medium for 5 days at $28^{\circ} \mathrm{C}$ while shaking at 200 r.p.m., and the culture broth (24l) was centrifuged and then extracted three times with EtOAc. The mycelium was extracted three times by using acetone. After removal of acetone, the aqueous solution was extracted three times with EtOAc. EtOAc extracts from the culture filtrate and mycelia were combined and fractionated on a silica gel column using gradient starting from $100 \% \mathrm{CHCl}_{3}$ to $80 \% \mathrm{MeOH}$ to yield five fractions. The more polar fraction was separated on Sephadex $\mathrm{LH}-20(\mathrm{MeOH})$ followed by preparative HPLC, eluting with gradients of $\mathrm{CH}_{3} \mathrm{CN} / \mathrm{H}_{2} \mathrm{O}$ affording yoropyrazone $(1,5.2 \mathrm{mg})$.

Compound 1 (Figure 1, Table 1) was obtained as a yellow solid. On the TLC after developing, it showed green fluorescence under UV light $(365 \mathrm{~nm})$ and turned reddish brown after spraying with Dragendorff's reagent. It showed an $[\mathrm{M}-\mathrm{H}]^{-}$ion at $m / z 571.2021$ in the HRESIMS, which was consistent with the molecular formula $\mathrm{C}_{27} \mathrm{H}_{31} \mathrm{~N}_{4} \mathrm{O}_{10}$ (calcd for 571.2040). Its UV spectrum with absorption maxima at $\lambda_{\max } 408$ and $275 \mathrm{~nm}$ was indicative of quinone chromophore. The ${ }^{13} \mathrm{C}$ NMR and DEPT spectra of 1 with the aid of HMQC data (Table 1) showed the presence of 27 carbon signals, which were recognized as three methyl carbons $\left[\delta_{\mathrm{C}} 21.5\left(\mathrm{OCOCH}_{3}-4^{\prime}\right), 20.9\left(\mathrm{C}-7^{\prime}\right)\right.$ and $\left.20.2(\mathrm{C}-19)\right]$; four methylenes $\left[\delta_{\mathrm{C}} 43.4(\mathrm{C}-1 \overline{6}), 37.8\left(\mathrm{C}-5^{\prime}\right), 32.5(\mathrm{C}-11)\right.$ and 27.9 $(\mathrm{C}-13)]$; six oxymethine carbons $\left[\delta_{\mathrm{C}} 72.2\left(\mathrm{C}-4^{\prime}\right), 70.6(\mathrm{C}-18), 67.8\right.$ $\left(\mathrm{C}-3^{\prime}\right), 66.6(\mathrm{C}-17), 65.7(\mathrm{C}-12)$ and $\left.62.7\left(\mathrm{C}-6^{\prime}\right)\right]$; one quaternary carbon $\left[\delta_{\mathrm{C}} 101.0(\mathrm{C}-2)\right]$, two $s p^{2}$ methines $\left[\delta_{\mathrm{C}} 136.3(\mathrm{C}-4)\right.$ and 122.5 $(\mathrm{C}-5)]$; seven $s p^{2}$ quaternary carbons $\left[\delta_{\mathrm{C}} 158.0(\mathrm{C}-6), 133.3\right.$ (C-10a), 132.2 (C-7a), 123.6 (C-2a), 117.5 (C-10b), $112.2(\mathrm{C}-7)$ and 106.3 (C-3a)]; and four carbonyl groups $\left[\delta_{\mathrm{C}} 186.6\right.$ (C-3), 177.3 (C-14), $173.5\left(\mathrm{OCOCH}_{3}-4^{\prime}\right)$ and $\left.160.6(\mathrm{C}-8)\right]$. In the ${ }^{1} \mathrm{H}$ NMR spectra of 1 (Table 1), two ortho-coupled aromatic protons $\left[\delta_{\mathrm{H}} 7.97(\mathrm{~d}, J=8.7 \mathrm{~Hz}\right.$, $\mathrm{H}-4)$ and $6.55(\mathrm{~d}, J=8.7 \mathrm{~Hz}, \mathrm{H}-5)]$; six oxymethine protons $\left[\delta_{\mathrm{H}} 5.31\right.$ (ddd, $J=13.1,4.1$ and $\left.3.9 \mathrm{~Hz}, \mathrm{H}-4^{\prime}\right), 5.04\left(\mathrm{~d}, J=3.9 \mathrm{~Hz}, \mathrm{H}-3^{\prime}\right), 4.85$ (m, $\mathrm{H}-17), 4.57$ (m, H-12), $4.51\left(\mathrm{~m}, \mathrm{H}-6^{\prime}\right)$ and $4.31(\mathrm{qd}, J=6.0$ and $8.9 \mathrm{~Hz}$, $\mathrm{H}-18)$ ]; four methylene signals $\left[\delta_{\mathrm{H}} 3.31(\mathrm{~m}, \mathrm{H}-16 \mathrm{a}), 3.08\right.$ (dd, $J=11.6$ and $15.5 \mathrm{~Hz}, \mathrm{H}-16 \mathrm{~b}), 2.81(1 \mathrm{H}, \mathrm{dd}, J=11.6$ and $2.9 \mathrm{~Hz}, \mathrm{H}-11 \mathrm{a}), 2.79$ $(1 \mathrm{H}, \mathrm{dd}, J=11.6$ and $10.2 \mathrm{~Hz}, \mathrm{H}-1 \mathrm{lb}), 2.75\left(2 \mathrm{H}, \mathrm{m}, \mathrm{H}_{2}-13\right), 1.89(\mathrm{~m}$, $\mathrm{H}-5^{\prime} \mathrm{a}$ ) and 1.87 (ddd, $J=14.2,4.1$ and $2.4 \mathrm{~Hz}, \mathrm{H}-5^{\prime} \mathrm{b}$ )]; one methyl singlet $\left[\delta_{\mathrm{H}} 1.99\left(\mathrm{~s}, 4^{\prime}-\mathrm{OCOCH}_{3}\right)\right]$; and two methyl doublets $\left[\delta_{\mathrm{H}} 1.33\right.$ $\left(\mathrm{d}, J=6.0 \mathrm{~Hz}, \mathrm{H}_{3}-19\right)$ and $\left.\overline{1.20}\left(\mathrm{~d}, J=5.7 \mathrm{~Hz}, \mathrm{H}_{3}-7^{\prime}\right)\right]$ were observed. Detailed analysis of the 2D NMR spectra $\left({ }^{1} \mathrm{H}-{ }^{1} \mathrm{H}\right.$ COSY, HMQC and $\mathrm{HMBC}$ ) of 1 led to the assignment of three fragments I-III (Figure 2). In fragment $\mathrm{I}$, the ${ }^{1} \mathrm{H}-{ }^{1} \mathrm{H}$ COSY spectrum revealed the presence of two partial structures as follows: $\left[\mathrm{CH}_{3}-\mathrm{CH}(\mathrm{O})-\mathrm{CH}_{2}-\right.$ $\mathrm{CH}(\mathrm{O})-\mathrm{CH}(\mathrm{O})-]$ and $\left[-\mathrm{CH}_{2}-\mathrm{CH}(\mathrm{O})-\mathrm{CH}_{2}-\mathrm{CO}-\right]$. The $\mathrm{HMBC}$ couplings from $\mathrm{H}_{3}-7^{\prime}\left(\delta_{\mathrm{H}} 1.20\right)$ to $\mathrm{C}-5^{\prime}\left(\delta_{\mathrm{C}} 37.8\right)$ and $\mathrm{C}-6^{\prime}\left(\delta_{\mathrm{C}} 62.7\right)$;

${ }^{1}$ Chemistry Department, Faculty of Science, Helwan University, Cairo, Egypt and ${ }^{2}$ Graduate School of Pharmaceutical Sciences, Chiba University, Chiba, Japan Correspondence: Professor M Ishibashi, Graduate School of Pharmaceutical Sciences, Chiba University, 1-8-1 Inohana, Chuo-ku, Chiba 260-8675, Japan. E-mail: mish@chiba-u.jp

Received 26 December 2011; revised 22 January 2012; accepted 2 February 2012; published online 22 February 2012 


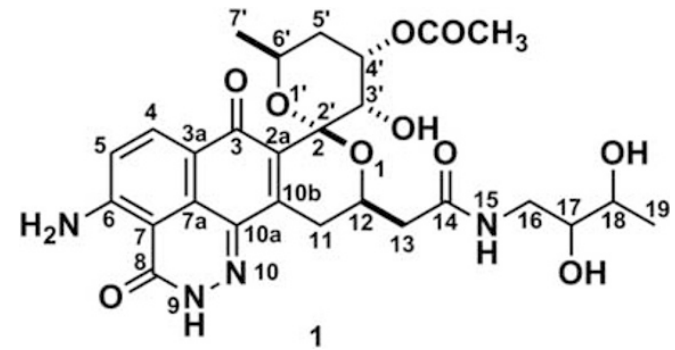

Figure 1 Structure of yoropyrazone (1).

Table $1{ }^{1} \mathrm{H}(600 \mathrm{MHz})$ and ${ }^{13} \mathrm{C}$ NMR data $(125 \mathrm{MHz})$ of compound 1 in $\mathrm{CD}_{3} \mathrm{OD}$

\begin{tabular}{|c|c|c|c|}
\hline No. & $\delta_{H}$ mult. $(\mathrm{J}$ in $\mathrm{Hz})$ & $\delta_{C}$ & $H M B C(H \rightarrow C)$ \\
\hline 2 & & 101.0 & \\
\hline $2 a$ & & 123.6 & \\
\hline 3 & & 186.6 & \\
\hline $3 a$ & & 106.3 & \\
\hline 4 & $7.97(1 \mathrm{H}, \mathrm{d}, 8.7)$ & 136.3 & $\mathrm{C}-3, \mathrm{C}-6, \mathrm{C}-7 \mathrm{a}$ \\
\hline 5 & $6.55(1 \mathrm{H}, \mathrm{d}, 8.7)$ & 122.5 & C-3a, C-7 \\
\hline 6 & & 158.0 & \\
\hline 7 & & 112.2 & \\
\hline $7 a$ & & 132.2 & \\
\hline 8 & & 160.6 & \\
\hline $10 a$ & & 133.3 & \\
\hline $10 \mathrm{~b}$ & & 117.5 & \\
\hline \multirow[t]{2}{*}{11} & a) $2.81(1 \mathrm{H}, \mathrm{dd}, 11.6,2.9)$ & 32.5 & C-2a, C-10a, C-10b, C-13 \\
\hline & b) $2.79(1 \mathrm{H}, \mathrm{dd}, 11.6,10.2)$ & & \\
\hline 12 & $4.57(1 \mathrm{H}, \mathrm{m})$ & 65.7 & C-14 \\
\hline 13 & $2.75(2 \mathrm{H}, \mathrm{m})$ & 27.9 & C-12, C-14 \\
\hline 14 & & 177.3 & \\
\hline 16 & $\begin{array}{l}\text { a) } 3.31(1 \mathrm{H}, \mathrm{m}) \text {, } \\
\text { b) } 3.08(1 \mathrm{H}, \mathrm{dd}, 11.6,15.5)\end{array}$ & 43.4 & C- $14, \mathrm{C}-18$ \\
\hline 17 & $4.85(1 \mathrm{H}, \mathrm{m})$ & 66.6 & \\
\hline 18 & $4.31(1 \mathrm{H}, \mathrm{qd}, 6.0,8.9)$ & 70.6 & C-19 \\
\hline 19 & $1.33(3 \mathrm{H}, \mathrm{d}, 6.0)$ & 20.2 & $\mathrm{C}-17, \mathrm{C}-18$ \\
\hline $3^{\prime}$ & $5.04(1 \mathrm{H}, \mathrm{d}, 3.9)$ & 67.8 & \\
\hline $4^{\prime}$ & $5.31(1 \mathrm{H}, \mathrm{ddd}, 13.1,4.1,3.9)$ & 72.2 & $C-6^{\prime}$ \\
\hline $4^{\prime}-\mathrm{OCOCH}_{3}$ & $1.99(3 \mathrm{H}, \mathrm{s})$ & 21.5 & oco- $4^{\prime}$ \\
\hline $4^{\prime}-\mathrm{OCOCH}_{3}$ & & 173.5 & \\
\hline \multirow[t]{2}{*}{$5^{\prime}$} & a) $1.89(1 \mathrm{H}, \mathrm{m})$ & 37.8 & $C-4^{\prime}, C-6^{\prime}$ \\
\hline & b) $1.87(1 \mathrm{H}, \mathrm{ddd}, 14.2,4.1,2.4)$ & & \\
\hline $6^{\prime}$ & $4.51(1 \mathrm{H}, \mathrm{m})$ & 62.7 & $\mathrm{C}-2^{\prime}$ \\
\hline $7^{\prime}$ & $1.20(3 \mathrm{H}, \mathrm{d}, 5.7)$ & 20.9 & $C-5^{\prime}, C-6^{\prime}$ \\
\hline
\end{tabular}

H-6 $\left(\delta_{\mathrm{H}} 4.51\right)$ to $\mathrm{C}-2\left(\delta_{\mathrm{C}} 101.0\right)$; H-4 ${ }^{\prime}\left(\delta_{\mathrm{H}} 5.31\right)$ to $\mathrm{C}-6^{\prime}\left(\delta_{\mathrm{C}} 62.7\right)$; $4^{\prime}-\mathrm{OCOCH}_{3}\left(\delta_{\mathrm{H}} 1.99\right)$ to the acetate carbonyl group $\left(\delta_{\mathrm{C}} 173.5\right) ; \mathrm{H}_{2}-5^{\prime}$ $\left(\delta_{\mathrm{H}} 1.89\right.$ and 1.87$)$ to $\mathrm{C}-4^{\prime}\left(\delta_{\mathrm{C}} 72.2\right)$ and C-6' $\left(\delta_{\mathrm{C}} 62.7\right)$; and $\mathrm{H}_{2}-11$ $\left(\delta_{\mathrm{H}} 2.80\right)$ to $\mathrm{C}-13\left(\delta_{\mathrm{C}} 27.9\right)$ confirmed the structure of fragment I. The position of the acetate group at C- $4^{\prime}$ was confirmed by comparing the NMR data with (+)-griseusin A. ${ }^{7}$ The proposed structure of fragment I was also contained in pyranonaphthoquinone compounds isolated previously from this strain. ${ }^{4}$ Fragment II was identified as aminobutane-2,3-diol from the ${ }^{1} \mathrm{H}-{ }^{1} \mathrm{H}$ COSY experiments depicted in Figure 2. It was also confirmed by $\mathrm{HMBC}$ correlations of $\mathrm{H}_{3}-19\left(\delta_{\mathrm{H}} 1.33\right)$ to C-17 $\left(\delta_{\mathrm{C}} 66.6\right)$ and C-18 $\left(\delta_{\mathrm{C}} 70.6\right)$. By considering the chemical shift of $\mathrm{C}-16\left(\delta_{\mathrm{C}} 43.4\right)$ and the HMBC couplings of $\mathrm{H}_{2}-16\left(\delta_{\mathrm{H}} 3.31\right.$ and

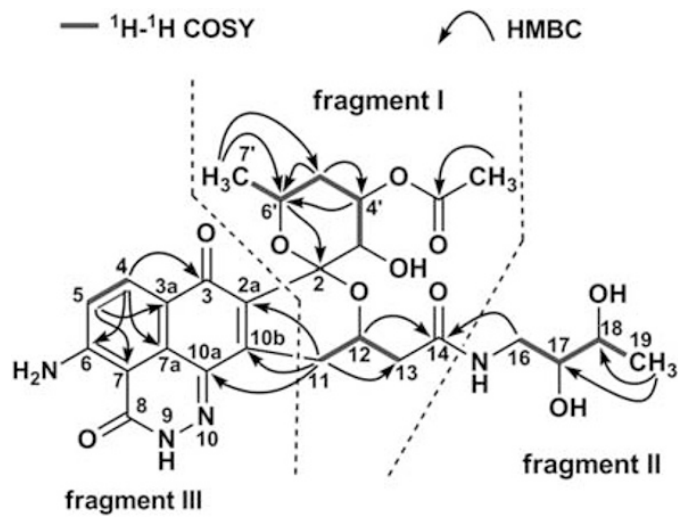

Figure 2 Key COSY and HMBC correlations of yoropyrazone (1). A full color version of this figure is available at The Journal of Antibiotics online.
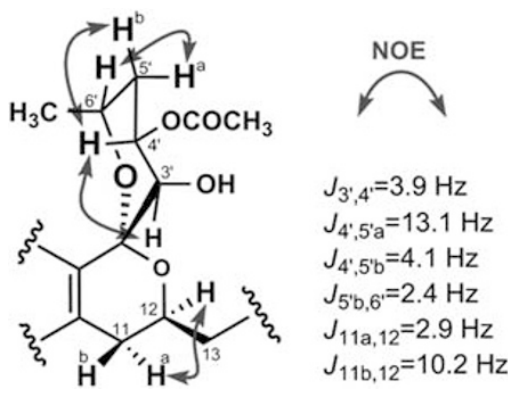

Figure 3 Key NOE correlations and coupling constants of yoropyrazone (1). A full color version of this figure is available at The Journal of Antibiotics online.

3.08) and H-12 $\left(\delta_{\mathrm{H}} 4.57\right)$ to the carbonyl group C-14 $\left(\delta_{\mathrm{C}} 177.3\right)$, fragments II and I were linked by an amide bond. In fragment III, the HMBC cross-peaks of the aromatic proton $\mathrm{H}-4\left(\delta_{\mathrm{H}} 7.97\right)$ to C-3 $\left(\delta_{\mathrm{C}}\right.$ 186.6), C-6 $\left(\delta_{\mathrm{C}} 158.0\right)$ and C-7a $\left(\delta_{\mathrm{C}} 132.2\right)$ fixed $\mathrm{H}-4$ at a peri-position to the carbonyl group at $\mathrm{C}-3$. The $\mathrm{HMBC}$ couplings of $\mathrm{H}_{2}-11$ allowed $\mathrm{C}-2 \mathrm{a}, \mathrm{C}-10 \mathrm{a}$ and $\mathrm{C}-10 \mathrm{~b}$ to be assigned. By considering the chemical shift of C-10a ( $\delta_{\mathrm{C}} 133.3$ p.p.m.) (For pyridazine-3(2H)-one, C-6, which is the corresponding position of C-10a of 1 , resonated at $\delta_{C}$ $139.02 .{ }^{8}$ For a phenylacetic acid hydrazide derivative NG-061, C-8, the corresponding position of $\mathrm{C}-10 \mathrm{a}$ of 1 , resonated at $\left.\delta_{C} 132.8 .^{9}\right)$ with the remaining three nitrogen atoms unassigned, fragment III was elucidated as naphthopyridazone with an amino group on C-6. The ${ }^{1} \mathrm{H}$ NMR spectrum of 1 in DMSO- $d_{6}$ solution showed a signal due to the amino group at $\delta_{\mathrm{H}} 13.5(2 \mathrm{H}$, broad singlet), which was consistent with the chemical shift value $\left(\delta_{\mathrm{H}} 13.2,2 \mathrm{H}\right)$ of the corresponding amino group of a synthetic compound, 8-amino-2-methyl-2,7-dihydro- $3 \mathrm{H}$ dibenzo[ $[e, h]$ cinnoline-3,7-dione. ${ }^{10}$ By combining all of the above evidence, the structure of yoropyrazone was concluded as 1 , shown in Figure 1. The assignment of the relative configuration of yoropyrazone (1) was established from the NOE observed between the vicinal protons $\mathrm{H}-3^{\prime}$ and $\mathrm{H}-4^{\prime}$, and their coupling constant of $3.9 \mathrm{~Hz}$ $\left(J_{\mathrm{H}-3^{\prime}, \mathrm{H}-4^{\prime}}=4.0 \mathrm{~Hz}\right.$ in $4^{\prime}$-deacetyl-(-)-griseusin B). ${ }^{11}$ Additionally, observation of NOE between H-4' and H-5'b, H-6 ${ }^{\prime}$ and H-5'a, and $\mathrm{H}-11 \mathrm{a}$ and $\mathrm{H}-12$ suggested the stereochemistry of C- $4^{\prime}$ and $\mathrm{C}-6^{\prime}$, as shown in Figure 3. On the basis of the NOE and coupling constants ( $J=10.2$ and 2.9; Figure 3 ), hydrogen on C-12 is axially oriented and a side chain starting from $\mathrm{C}-13$ is equatorially oriented. The absolute stereochemistry of fragment I was suggested to be identical to the 


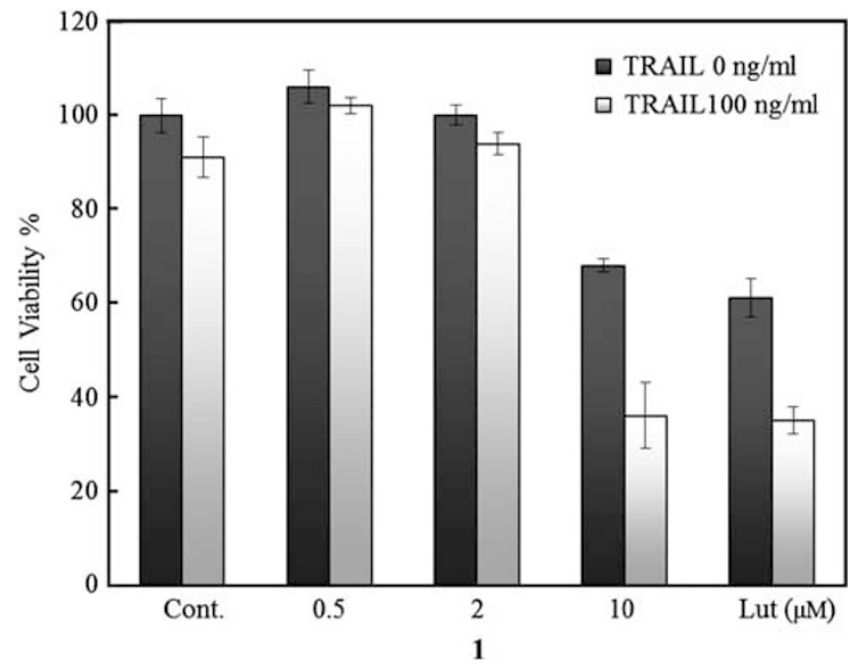

Figure 4 Effect of compound 1 on the cell viability of AGS cells in the presence and absence of TRAIL. The standard error bar represents the means $(n=3 \pm$ s.d.). A full color version of this figure is available at The Journal of Antibiotics online.

recently isolated pyranonaphthoquinones ${ }^{4}$ on the basis of similar CD spectral data, implying that fragment I of 1 had $2 S, 3^{\prime} S, 4^{\prime} S, 6^{\prime} S$ configuration. The stereochemical relationship of C-12 position with the tetrahydropyran ring moiety $\left(\mathrm{C}-2, \mathrm{C}-3^{\prime}, \mathrm{C}-4^{\prime}\right.$ and $\mathrm{C}-6^{\prime}$ positions) may remain arbitrary but is likely to be the same as compounds previously isolated together from this strain. ${ }^{4}$ The coupling constant of 1,2-diol moiety $\left(J_{\mathrm{H}-17, \mathrm{H}-18}\right)$ in the aminobutane-2,3-diol side chain (fragment II) was revealed to be $8.9 \mathrm{~Hz}$ from the ${ }^{1} \mathrm{H}$ NMR spectrum in DMSO- $d_{6}$ solution of 1 ; however, the $J$ values of the corresponding positions of threo and erythro isomers of 1-(4-hydroxyphenyl) butane-2,3-diol $\left(J_{\text {threo }}=8.6 \mathrm{~Hz} \text { and } J_{\text {erythro }}=2.3 \mathrm{~Hz}\right)^{12}$ and nhatrangins $\mathrm{A}\left(J_{\text {threo }}=4.2 \mathrm{~Hz}\right)^{13}$ in the literature vary depending on the neighboring structure. Thus, the relative configuration of the C-17/C-18 position of 1 remains undefined presently. Some naphthoquinones fused with the pyridazone ring were synthetically prepared and exhibited cytotoxic activities. ${ }^{14}$ To the best of our knowledge, yoropyrazone (1) is the first example of microbial naphthopyridazone natural products.

The biological activity of compound $\mathbf{1}$ was evaluated for its effect on TRAIL resistance in AGS cells. Recently, this cell line has been widely used as a model system for evaluating cancer cell apoptosis and is reported to be refractory to apoptosis induction by TRAIL. ${ }^{15}$ To assess the effect of compound $\mathbf{1}$ on cell viability in the presence and absence of TRAIL, AGS cells were treated with 1 and subjected to the Fluorometric microculture cytotoxicity assay method. ${ }^{16}$ Luteolin was used as a positive control at $17.5 \mu \mathrm{M},{ }^{17}$ and the assay results are summarized in Figure 4. Compound $\mathbf{1}$ at $10 \mu \mathrm{m}$ reduced cell viability to $68 \%$ of the control level, whereas combined treatment along with $100 \mathrm{ng} \mathrm{ml}^{-1}$ TRAIL further reduced the cell viability to $36 \%$ of control levels, which was $32 \%$ more than the agent alone. Compound 1 also showed cytotoxicity against human gastric AGS cells with $\mathrm{IC}_{50}=12.5 \mu \mathrm{M}$. These results suggested that compound $\mathbf{1}$ in the presence of TRAIL showed a moderate TRAIL resistance-overcoming activity against AGS cells. The resistance of cancer cells toward TRAIL may occur at different points in the TRAIL-induced apoptotic pathways. Understanding the mechanisms of such resistance and developing strategies to overcome it are important for the successful use of TRAIL in cancer therapy. Combined treatment with TRAIL and chemotherapeutic agents, including natural products, can overcome such resistance and sensitize TRAIL-resistant cells to enhance the therapeutic potential of TRAIL against cancer cells; therefore, a natural product having TRAIL resistance-overcoming activity would be a new tool for investigating cancer cells. ${ }^{18}$ In this study, we reported for the first time the cytotoxic activity of naphthopyridazone derivative in the presence of TRAIL against TRAIL-resistant AGS cells, thereby suggesting their possible use in combination with TRAIL against human gastric adenocarcinoma.

\section{METHODS}

\section{General experimental procedures}

Optical rotations were measured with a JASCO P-1020 polarimeter (JASCO, Tokyo, Japan). IR spectra were recorded on attenuated total reflection using a Jasco FT-IR 230 spectrophotometer, and UV spectra were obtained on a Shimadzu UV mini-1240 spectrometer. NMR data were measured on a JEOL JNM ecp600 spectrometer. Mass spectra were recorded on an AccuTOF-T100LP (JEOL) mass spectrometer.

\section{Producing strain}

Strain IFM11307 was isolated from a soil sample collected from Ichihara-shi, Chiba prefecture, Japan in $2007 .{ }^{4}$ It was identified as Streptomyces sp. and deposited in the Medical Mycology Research Center, Chiba University, Japan with code number IFM 11307. The strain was identified by the sequence analysis of $16 \mathrm{~S}$ rRNA, which showed that the strain has $99.8 \%$ identity to Streptomyces griseus.

\section{Fermentation}

Strain Streptomyces sp. IFM 11307 was cultivated, from glycerol stock, on Waksman agar medium containing glucose $2 \mathrm{~g}$, meat extract $0.5 \mathrm{~g}$, peptone $0.5 \mathrm{~g}$, dried yeast $0.3 \mathrm{~g}, \mathrm{NaCl} 0.5 \mathrm{~g}, \mathrm{CaCO}_{3} 0.3 \mathrm{~g}$ and agar $1.5 \mathrm{~g}$ in $100 \mathrm{ml}$ water. Pieces of agar $\left(1 \mathrm{~cm}^{2}\right)$ cultures were used to inoculate $4 \times 500-\mathrm{cm}^{3}$ Sakaguchi flasks, each containing $100 \mathrm{ml}$ Waksman medium, under shaking ( 200 r.p.m.) at $28^{\circ} \mathrm{C}$ for 5 days. The subculture was used to inoculate $32 \times 3-1$ round flasks, each containing $750 \mathrm{ml}$ Waksman medium under the same conditions.

\section{Extraction and isolation}

A total of 241 broth was centrifuged at 3500 r.p.m. for $20 \mathrm{~min}$ to give the mycelium and water phase. The resulting mycelial cake was extracted three times with acetone. After removal of acetone, the aqueous solution was extracted three times with EtOAc. The EtOAc-soluble portion was concentrated under reduced pressure. The culture broth was extracted three times with EtOAc. As the TLC of both extracts from the culture filtrate and mycelia showed the same composition, they were combined and concentrated under reduced pressure. The crude extract $(7.2 \mathrm{~g})$ was subjected to chromatography on a silica gel column and successively eluted with a stepwise gradient of $\mathrm{CHCl}_{3} / \mathrm{MeOH}(100: 0-20: 80, \mathrm{v} / \mathrm{v})$ to afford five fractions (fraction I-V). The more polar fraction $\mathrm{V}$ was subjected to a Sephadex LH-20 and eluted with $\mathrm{MeOH}$ to give three sub-fractions (V1-V3). Fraction V2 was purified by preparative HPLC (Develosil ODS HG-5, $10 \times 250 \mathrm{~mm}$ ), eluting with gradients of $\mathrm{CH}_{3} \mathrm{CN} / \mathrm{H}_{2} \mathrm{O}$ at a flow rate of $1.0 \mathrm{ml} \mathrm{min}^{-1}$ to give compound $\mathbf{1}$ $\left(t_{\mathrm{R}}=15.3 \mathrm{~min}, 5.2 \mathrm{mg}\right)$.

Yoropyrazone (1). Yellow solid; $[\alpha]_{\mathrm{D}}^{22}+18.9(c 0.02, \mathrm{MeOH}) ; \mathrm{UV}(\mathrm{MeOH}) \lambda_{\max }$ $(\log \varepsilon): 408$ (2.9), $275(3.3)$ and $204(3.9) \mathrm{nm} ; \mathrm{CD}(\mathrm{MeOH}) \lambda_{\text {ext }}(\Delta \varepsilon) 414$ $(+0.012), 383(+0.008), 335(-0.004), 272(+0.014)$ and $233(-0.012) \mathrm{nm} ; \mathrm{IR}$ $v_{\max }$ (ATR) $\mathrm{cm}^{-1}: 3387,1710,1650,1489,1036$ and 799; (-)-HRESIMS $\mathrm{m} / \mathrm{z}$ (\%) 571.2021 (35) $[\mathrm{M}-\mathrm{H}]^{-}$(calcd for $\left.\mathrm{C}_{27} \mathrm{H}_{31} \mathrm{~N}_{4} \mathrm{O}_{10}, 571.2040\right), \mathrm{m} / z(\%)$ 570.1960 (100) $[\mathrm{M}-2 \mathrm{H}]^{-}$(calcd for $\left.\mathrm{C}_{27} \mathrm{H}_{30} \mathrm{~N}_{4} \mathrm{O}_{10}, 570.1962\right)$; (+)-HRESIMS 
$m / z(\%) 595.1984(35)[\mathrm{M}+\mathrm{Na}]^{+}$(calcd for $\mathrm{C}_{27} \mathrm{H}_{32} \mathrm{~N}_{4} \mathrm{O}_{10} \mathrm{Na}$, 595.2016), $m / z \quad \%$ ) 594.1918 (100) $[\mathrm{M}-\mathrm{H}+\mathrm{Na}]^{+}$(calcd for $\mathrm{C}_{27} \mathrm{H}_{31} \mathrm{~N}_{4} \mathrm{O}_{10} \mathrm{Na}$, 594.1938); ${ }^{1} \mathrm{H}$ NMR $\left(\mathrm{CD}_{3} \mathrm{OD}, 600 \mathrm{MHz}\right)$ and ${ }^{13} \mathrm{C}$ NMR $\left(\mathrm{CD}_{3} \mathrm{OD}\right.$, $125 \mathrm{MHz})$ data, see Table 1.

\section{Cell cultures}

AGS cells were derived from the Institute of Development, Aging and Cancer, Tohoku University. The cells were cultured in RPMI-1640 medium (Wako) with $10 \%$ fetal bovine serum and maintained in a humidified incubator at $37^{\circ} \mathrm{C}$ in $5 \% \mathrm{CO}_{2}$.

\section{Fluorometric microculture cytotoxicity assay}

AGS cells were seeded in a 96-well culture plate $\left(6 \times 10^{3}\right.$ cells per well $)$ in $200 \mu \mathrm{l}$ RPMI medium containing $10 \%$ fetal bovine serum. Cells were incubated at $37^{\circ} \mathrm{C}$ in a $5 \% \mathrm{CO}_{2}$ incubator for $24 \mathrm{~h}$. The test samples with or without TRAIL (Wako, $100 \mathrm{ng} \mathrm{ml}^{-1}$ ) at different doses were then added to each well. After $24 \mathrm{~h}$ incubation, the cells were washed with phosphate-buffered saline, and $200 \mu \mathrm{l}$ phosphate-buffered saline containing fluorescein diacetate $\left(10 \mu \mathrm{g} \mathrm{ml}^{-1}\right)$ was added to each well. The plates were then incubated at $37^{\circ} \mathrm{C}$ for $1 \mathrm{~h}$, and fluorescence was measured in a 96-well scanning spectrofluorometer at $538 \mathrm{~nm}$, following excitation at $485 \mathrm{~nm} .{ }^{16}$

\section{ACKNOWLEDGEMENTS}

We thank Professor Tohru Gonoi (Medical Mycology Research Center, Chiba University) for the identification of Streptomyces sp. IFM 11307. The research was supported by a Grant-in-Aid (22310133 and 23404007) for Scientific Research from the Japan Society for the Promotion of Science, a Grant-in-Aid (23102008) for Scientific Research on Innovative Areas 'Chemical Biology of Natural Products' from the Ministry of Education, Culture, Sports, Science and Technology, Japan (MEXT), Special Funds for Education and Research (Development of SPECT Probes for Pharmaceutical Innovation) from MEXT, the Iodine Research Project in Chiba University, and the Asian Core Program (JSPS). MS Abdelfattah thanks JSPS for a postdoctoral fellowship (ID No. P09042).
1 Abdelfattah, M. S., Toume, K. \& Ishibashi, M. Isolation and structure elucidation of izuminosides A-C: a rare phenazine glycosides from Streptomyces sp. IFM 11260. J. Antibiot. 64, 271-275 (2011).

2 Abdelfattah, M. S., Toume, K. \& Ishibashi, M. Izumiphenazines A-C: isolation and structure elucidation of phenazine derivatives from Streptomyces sp. IFM 11204. J. Nat. Prod. 73, 1999-2002 (2010).

3 Aida, W., Ohtsuki, T., Li, X. \& Ishibashi, M. Isolation of new carbamate- or pyridinecontaining natural products, fuzanins A, B, C, and D from Kitasatospora sp. IFM 10917. Tetrahedron 65, 369-373 (2009).

4 Abdelfattah, M. S., Toume, K. \& Ishibashi, M. New pyranonaphthoquinones and phenazine alkaloid isolated from Streptomyces sp. IFM 11307 with TRAIL resistance-overcoming activity. J. Antibiot. 64, 729-734 (2011).

5 Ishibashi, M. \& Ohtsuki, T. Studies on search for bioactive natural products targeting TRAIL signaling leading to tumor cell apoptosis. Med. Res. Rev. 28, 688-714 (2008).

6 Ahmed, F. et al. Constituents of Amoora cucullata with TRAIL resistance overcoming activity. Org. Biomol. Chem. 8, 3696-3703 (2010).

7 Kometani, T., Takeuchi, Y. \& Yoshii, E. Pyranonaphthoquinone antibiotics. 4. Total synthesis of (+)-griseusin A, an enantiomer of the naturally occurring griseusin A. J. Org. Chem. 48, 2311-2314 (1983).

$8 \mathrm{McNab}, \mathrm{H}$. An analysis of the ${ }^{13} \mathrm{C}$ n.m.r. spectra of pyridazin-3-ones and some specifically deuteriated derivatives. J. Chem. Soc., Perkin Trans. 1, 1203-1207 (1983).

9 Bhandari, R. et al. Structure of NG-061, a novel potentiator of nerve growth factor (NGF) isolated from Penicillium minioluteum F-4627. J. Antibiot. 52, 231-234 (1999).

10 Stefañska, B. et al. Synthesis and biological evaluation of 2,7-dihydro-3H-dibenzo $[d e, h]$ cinnoline-3,7-dione derivatives, a novel group of anticancer agents active on a multidrug resistant cell line. Bioorg. Med. Chem. 11, 561-572 (2003).

11 Igarashi, M. et al. 4'-Deacetyl-(-)-griseusins $A$ and $B$, new naphthoquinone antibiotics from an actinomycete. J. Antibiot. 48, 1502-1505 (1995)

12 Peng, X.- P. et al. Aromatic compounds from the halotolerant fungal strain of Wallemia sebi PXP-89 in ha hypersaline medium. Arch. Pharm. Res. 34, 907-912 (2011).

13 Chlipala, G. E. et al. Nhatrangins A and B, aplysiatoxin-related metabolites from the marine syanobacterium Lyngbya majuscule from Vietnam. J. Nat. Prod. 73, 784-787 (2010).

14 Stefañska, B. et al. 2,7-Dihydro-3H-pyridazino[5,4,3-k/] -acridin-3-one derivatives, novel type of cytotoxic agents active on multidrug-resistant cell lines. Synthesis and biological evaluation. Bioorg. Med. Chem. 13, 1969-1975 (2005).

15 Srivastava, R. K. TRAIL/Apo-2L: mechanisms and clinical applications in cancer. Neoplasia 3, 535-546 (2001).

16 Lindhagen, E., Mygren, P. \& Larsson, R. The fluorometric microculture cytotoxicity assay. Nat. Protoc. 3, 1364-1369 (2008).

17 Horinaka, M. et al. Luteolin induces apoptosis via death receptor 5 up regulation in human malignant tumor cells. Oncogene 24, 7180-7189 (2005).

18 Shankar, S. \& Srivastava, R. K. Enhancement of therapeutic potential of TRAIL by cancer chemotherapy and irradiation: mechanisms and clinical implication. Drug Resist. Updat. 7, 139-156 (2004). 